\title{
Ray Lee, 1931-2012: surgeon, teacher, mentor, friend
}

\author{
John Gebhart
}

Received: 21 April 2013 /Accepted: 24 April 2013 / Published online: 24 May 2013

(C) The International Urogynecological Association 2013

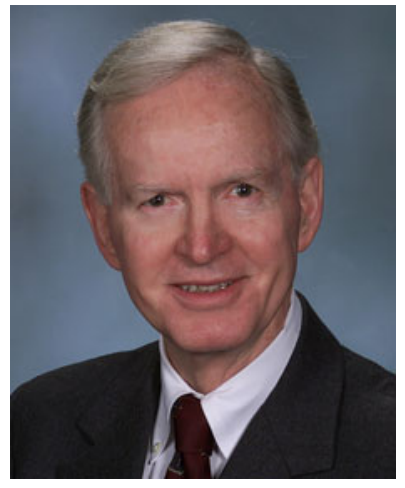

Ray joined the Mayo Clinic Department of OBGYN in 1965 and practiced as a general and gynecologic surgeon for 36 years. He deeply loved working at the clinic and felt honored to represent Mayo. Ray served in numerous and important capacities at Mayo such as the Division Head, the Board of Governors and Trustees, but he was also a member of the Teacher of the Year Hall of Fame, and was chosen by his Mayo colleagues for the Distinguished Clinician Award. Outside of Mayo, Ray served as President for several prestigious societies within gynecologic surgery, including the Society of Gynecologic Surgeons and the Society of Pelvic Surgeons. His vision was instrumental in developing the disciplines of urogynecology and reconstructive pelvic surgery in the United States. While leadership came easy to Ray his true passion was surgery and caring for patients.

Ray was regarded internationally as one of the premier gynecologic surgeons of his time. Someone respected and admired by all who knew him or heard him speak. He

J. Gebhart ( $\bowtie)$

Mayo Clinic, Rochester, MN, USA

e-mail: gebhart.john@mayo.edu gained that respect in large part because of his unparalleled surgical skills, but perhaps more so for his demeanor, his character, and his integrity. Friends and colleagues would describe Ray in many ways: hardworking, humble, kind, concise, always on time (more likely early, but never late), a good listener, a good teacher, humorous, someone who took pride in everything they did, dedicated to being the best and to giving his best, and devoted - to his family, his patients, and to Mayo Clinic and the House of Surgery.

Anyone who spent much time working with Ray learned that he spoke many great aphorisms. I'd like to share some thoughts from Ray.

Ray realized that it was important to get to know your patients:

Never operate on a stranger.

Communication will be critical to your practice. Be an excellent listener.

You have a tremendous responsibility and a privilege in the care of the sick. Kindness has not gone out of style. It is better to have your name etched in the heart of your patient than having it engraved in granite outside of a building.

When the surgical case got tough, Ray dug his heels in and was at his best:

Anyone can operate with good exposure and it's a shame not everyone tries it.

Avoid following complications with complications.

Your true measure as a surgeon will be determined by your performance during the most adverse circumstances. These experiences will develop your character and better prepare you for the next challenge.

Pay strict attention to details, keep the operative field dry, recheck the operative site...the anastomosis shows 
perfect approximation...free of tension and perfect hemostasis.

There is nothing hemostatic about a well-placed drain.

Ray took great pride in his work:

Do it in such a way that you would be willing to sign your name to it - the operation was performed by me. I'm convinced surgeons are made and not born. Be an active learner for the rest of your life. Commit yourself to staying up to date in this fast-changing arena. Many times it will be more difficult not to operate than it will be to operate. It is important to learn the things not to do.

Ray taught us the impact on surgeons of complications arising from surgery:

Errors and failures will make an indelible mark on your heart, and they should. Like a broken bone, it is better to experience this when you are young; albeit painful, it will heal faster. Be sure to learn something from each of your errors. You will never become so accomplished that there will not be room for improvement.
Lastly, Ray taught humility and compassion:

With success, never forget who you are, for we all have numerous reasons to be humble. Never let arrogance creep into your practice. Success can be more dangerous than occasional failure. Recognize areas of weakness so they can be identified, and goals can be set to correct them.

This book is dedicated to the patients for whom it is our privilege to care-Atlas of Gynecologic Surgery (1991). Applaud your colleagues in public; criticize them behind closed doors, one-on-one. When giving advice, be aware that it may be least appreciated by those who need it the most.

These quotes summarize Ray's thinking, and everyone who met Ray immediately recognized his outstanding characteristics as a surgeon, as a teacher and mentor, and as a human being.

Ray, who often quoted Helen Keller, knew that the best and most beautiful things in the world cannot be seen or even touched; they must be felt with the heart. Compassion, pride, humility, integrity-surgical lessons from Ray Lee, but also important life lessons. 